\title{
POLÍTICA, GÊNERO E RELIGIÃO NO PAQUISTÃO: IDENTIDADES EM DEBATE*
}

\author{
Farida Shaheed
}

\section{RESUMO}

No Paquistão, as forças não religiosas assim como as forças político-religiosas instrumentalizam cada vez mais o Islã em seu próprio benefício. Isto explica a crescente influência da religião e seu entrelaçamento com a nação em si mesma. A mudança de paradigma devida à lei marcial, sob Zia, deu ocasião ao surgimento de milícias religiosas e grupos desse tipo na sociedade civil. Mostrando que esta nem sempre é progressista, o artigo examina o impacto, variável segundo o seu estatuto social, da fusão entre religião e política para as mulheres, transformadas em marcadores identitários das posições conquistadas na corrida pelo poder. $\mathrm{O}$ artigo conclui que, uma vez que implica em mudança nas relações de poder, a igualdade entre os sexos não se dará sem uma luta tenaz para criar saber, cultura e identidade.

Palavras-chave: Paquistão. Religião. Islã. Direitos das mulheres. Discriminações. Violências. Público. Privado

\section{POLITIQUE, GENRE ET RELIGION AU PAKISTAN : IDENTITÉS EN DÉBAT}

\section{RÉSUMÉ}

Au Pakistan, des forces non religieuses, tout comme les forces politico-religieuses, instrumentalisent de plus en plus l'islam à leur profit. Cela explique l'influence croissante de la religion et son intrication avec la nation même. Le changement de paradigme dû à la loi martiale, sous Zia, a donné naissance à des milices religieuses

* Traduzido da versão francesa para o português por Eder William dos Santos. Revisão da tradução por Ana Claudia Miglioranza e Naira Pinheiro dos Santos. O texto original em francês, “POLITIQUE, GENRE ET RELIGION AU PAKISTAN : IDENTITÉS EN DÉBAT”, Cahiers du Genre, 2012/3 (HS n³), p. 27-46, foi traduzido do inglês por Jacqueline Heinen. 
et à des groupes du même cru dans la société civile. Montrant que celle-ci n'est pas toujours une entité progressiste, l'article examine l'impact variable, selon le statut social, de la fusion entre religion et politique pour les femmes, transformées en marqueurs identitaires des positions conquises dans la course au pouvoir. Il conclut que l'égalité des sexes, impliquant un changement des rapports de pouvoir, ne saurait advenir sans une lutte acharnée pour créer du savoir, de la culture et de l'identité.

Mots-clés: Pakistan. Religion. Islam. Droits des femmes. Discriminations. Violences. Public. Privé.

A fusão do político e do religioso e seu impacto sobre as mulheres é frequentemente abordada sob o ângulo exclusivo da ciência política e centrada na dinâmica do poder do Estado. Tal abordagem é insuficiente. Ora, a interação entre religião, política e gênero ilustra a impossibilidade de separar o social do político, o público do privado. Pois as distinções teóricas entre o que se refere à cultura, à política, ao social ou à economia se desvanecem na realidade. As mobilizações públicas das mulheres se inscrevem frequentemente em campos definidos mais como sociais do que como políticos, ao passo que os discursos políticos pesam sobre o cotidiano, tal qual os fatores culturais e econômicos. Note-se que todos os projetos político-religiosos comportam prescrições de gênero bem definidas, tais como códigos de vestimenta, reclusão ou obstrução à inserção das mulheres no mercado de trabalho. Conformando-se a estas injunções, elas se tornam fortes marcadores simbólicos do território político 'conquistado'.

A religião sempre esteve ligada à política no Paquistão - Estado criado para os muçulmanos indianos. Mas, não é algo tão evidente o fato de que o Islã, identidade religiosa majoritária, tenha se tornado a referência central do Estado e da sociedade. Quer elas emanem de atores não religiosos, da elite civil e política ou do aparelho militar, as manobras que visam explorar a carga emocional (para reprimir a oposição política ou justificar medidas não democráticas) transformaram a religião em moeda política, permitindo às forças político-religiosas afirmarem a sua hegemonia. Ao negar os compromissos do Estado para com a igualdade das mulheres e dos/as não-muçulmanos/as, o general Zia-ul-Haq (19771988 ) incentivou as camadas mais religiosas da sociedade. 
Por que o legado do ditador mais impopular do Paquistão persiste, mesmo tanto tempo após a sua morte? Este artigo mapeia, primeiramente, o modo pelo qual a utilização oportunista do Islã por atores sem conotação religiosa, tanto quanto por aqueles que se definem como religiosos, levou à politização da religião. Verifica-se aí que o impacto duradouro da era Zia, em matéria de gênero, se deve tanto à reformulação de costumes, quanto de leis e de políticas públicas, e que o processo de 'islamização' teve impactos variáveis para as mulheres, de acordo com o seu estatuto social. Examinam-se, em seguida, os obstáculos aos projetos de igualdade entre os sexos que, frequentemente, se dirigem ao Estado, são desprovidos de agenda cultural e são portadores de um discurso sobre os direitos humanos sem grande relação com a moral vigente.

\section{FUNDIR O ISLÃ NA REPÚBLICA}

O fundador do Paquistão, Mohammad Ali Jinnah, preconizava um Estado laico e não teocrático'. No entanto, o paradoxo é que, apesar das suas repetidas derrotas eleitorais, os partidos político-religiosos conseguiram substituir a criação de um Estado 'para os muçulmanos' por um 'Estado islâmico', permitindo assim a uma minoria fazer pouco da opinião da maioria. Este processo começou no momento em que o Estado estava em formação e quando a credibilidade da maioria dos ulemás (eruditos religiosos) politicamente ativos encontrava-se seriamente afetada pelo fato de terem se oposto à criação do Paquistão. Devemos, portanto, buscar as razões de tal dinâmica fora das esferas político-religiosas.

Pouco após a morte de Jinnah, a aprovação da Resolução sobre os Objetivos de 1949 constituiu uma vitória crucial para redefinir os contornos do Estado. Ela foi adotada por uma Assembleia Constituinte na qual membros religiosos ocupavam um espaço ínfimo, e contra a opinião dos/as não-muçulmanos/as². Maulana Abul A'la Maududi, fundador da Jamaat-i-Islami (J) desempenhou então um papel decisivo: sua

1 Este projeto figura no discurso de Jinnah à Assembléia Constituinte, a 11 de agosto de 1947. Posteriormente, Zia suprimiu a totalidade do texto.

2 A resolução encoraja uma vida "de acordo com os ensinamentos e as exigências do Islã", enquanto a Constituição não faz mais do que proteger os "direitos legítimos" das minorias. 
nova missão era fazer da xaria - a qual constitui 'um modo espiritual de viver' ou 'um caminho individual em direção a deus para o/a crente muçulmano/a' - o fundamento do sistema jurídico do novo Estado. Décadas mais tarde, em 1977, os partidos político-religiosos alimentaram a mobilização popular contra a fraude eleitoral, apoiando-se numa coalizão heterogênea de partidos e, no desde então famoso mantra, que assimila o Paquistão unicamente ao credo muçulmano.

No plano social, os dirigentes não tinham um programa cultural coerente: o seu 'liberalismo incerto' dobra-se sistematicamente à vontade inflexível da 'ortodoxia religiosa' (Rashid, 1986). Nessa batalha, toda sorte de imperativos forjados da 'nação muçulmana' serviu para recusar um pouco de autonomia às diversas entidades linguísticas e étnicas que compõem o Paquistão; os agrupamentos político-religiosos encorajavam e apoiavam os ataques contra os grupos de esquerda, chamados de 'não islâmicos' e de 'inspiração estrangeira' (Abbas, 2005).

Após a independência, as elites dirigentes que se sucederam no poder, abandonaram a construção de uma nação ancorada na questão territorial, o que teria possibilitado reunir os numerosos grupos linguísticos e étnicos. Encorajados pelo declínio dos/as não muçulmanos/as entre a população, eles escolheram moldar uma identidade nacional fundada na religião, sem levar em conta que isso constituiria um trampolim dos mais eficazes para os grupos político-religiosos. O país oscilou, assim, entre regime presidencial e regime parlamentar, entre longos períodos de lei marcial e breves fases de regime civil precário, além de frequentes remanejamentos radicais da Constituição.

Não fora o fato dos não religiosos terem utilizado tão frequentemente o Islã para fins políticos, contribuindo assim para promover a noção de 'nação muçulmana', os grupos político-religiosos não teriam podido inscrever a religião de forma tão consistente no âmago mesmo dos textos políticos, do Estado e da sociedade. Os detentores do poder cederam de forma sistemática às exigências da direita religiosa para restringir tanto os direitos quanto o espaço atribuído às mulheres. A começar pelo fechamento, em 1954, da Guarda Nacional e da Reserva Naval Feminina, na sequência dos protestos de atores religiosos de segunda linha, para os quais os cursos de autodefesa ministrados por homens às jovens mulheres eram contrários ao Islã. 
O Islã continuou a impregnar a esfera política sob os governos progressistas, ainda que em um sentido diferente. Sob Zulfikar Ali Bhutto (1971-1977), o 'socialismo islâmico', decretou que "a discriminação contra as mulheres é contrária às injunções do Islã" (Declaration of the Rights of Pakistani Women, 1976) e adotou artigos constitucionais que promoviam uma ação positiva. Entretanto, a Constituição de 1973 privilegiava os muçulmanos: não se tocou nos códigos de família discriminatórios e fundamentados nas religiões e criou-se um Ministério de Assuntos Religiosos. No plano social, as ligações com o Oriente Médio permitiram, infelizmente, moldar uma identidade coletiva semelhante à dos detentores de petrodólares. Em 1977, a fim de ganhar a aprovação da direita religiosa, Bhutto chegou até mesmo a introduzir uma série de medidas cosméticas de tipo 'islâmicas': proibição de bebidas alcoólicas e de jogos de azar, sexta-feira decretada como dia de folga semanal, etc.

A 'islamização' visava modificar o equilíbrio dos poderes - sendo que o principal objetivo dos grupos político-religiosos era o de se apropriar do poder do Estado (ou de conservá-lo). A marginalização deliberada das mulheres (e das minorias não muçulmanas) operada sob Zia foi um meio eficaz de se impor, ainda que acessório face à aliança entre o exército e a mesquita. De acordo com o objetivo pretendido, o exército combatia pela força os grupos e partidos religiosos, ou fazia aliança com eles. Até então ele nunca tinha assumido o papel de 'defensor da fé', sem se posicionar, no entanto, como defensor da laicidade à moda turca, ainda que os oficiais aparecessem geralmente como laicos. Zia aniquilou completamente a tradição laica do exército. Ora, devido ao próprio peso do corpo mais poderoso de um Estado que é a sexta potência militar do mundo, com mais de meio milhão de soldados, toda e qualquer mudança de atitude no seu seio tem necessariamente repercussões sobre a sociedade. $\mathrm{Na}$ área de segurança, o exército queria ocupar um lugar estratégico, que recaía sobre o vizinho Afeganistão, e vender a ideia (em particular para os EUA) de que ele constituía uma 'barreira islâmica contra os soviéticos' (Jalal, 1991).

Não se pode subestimar o papel que o Paquistão desempenhou na guerra por procuração dos EUA no Afeganistão. Todo questionamento sobre o modo como Zia utilizava o Islã para justificar seu regime ilegal, 
suprimir os direitos das mulheres ou instaurar medidas antidemocráticas e punições bárbaras era desconsiderado, já que o discurso internacional promovido pelos americanos saudava e legitimava os mujahidins como combatentes da liberdade. O termo 'mujahidin' significa, literalmente, aquele que leva uma guerra santa ou jihad, e esse rótulo foi aplicado a todo militante político-religioso. O apelo à guerra santa contra os inimigos ímpios do Islã no Afeganistão inspiraria toda uma geração de novos islamistas entre os militares no Paquistão (Hussain, 2007). A complexidade das ligações tecidas entre alguns seminários religiosos (Madraças ${ }^{3}$ ), os grupos militantes armados, os mujahidins e o Estado militar, durante e depois da guerra no Afeganistão (Abbas, 2005), borrou as fronteiras entre atores estatais e não estatais, o que permitiu aos atores não estatais político-religiosos avançarem os seus peões a todos os níveis da sociedade e quase sem limite algum - inclusive através de ações armadas.

\section{AS MULHERES, O ESTADO E O ISLÃ: REALIDADES E IMPACTO DI- FERENTES}

Antes de 1977, as mulheres foram, certamente, vítimas de negligências graves por parte do Estado, com as ideias patriarcais bloqueando qualquer progresso. Porém, sob Zia, uma ‘islamização’ punitiva, antidemocrática e misógina e mudanças jurídicas, institucionais e de normas sociais foram acompanhadas pela incitação a práticas religiosas provenientes do Estado. Nenhum governo anterior havia jamais lançado um programa social conferindo tal lugar ao gênero. Apoiando-se em estruturas profundamente patriarcais, essa dinâmica visava transformar cada cidadão/ã num/a executor/a voluntário/a e cúmplice do projeto do Estado.

Entretanto, diversos fatores, que não dizem respeito diretamente ao quadro político, intervieram na questão: estruturas de arbitragem tradicionais encarregadas de regulamentar os litígios, que frequentemente prevalecem sobre mecanismos estatais; redes clientelares de ordem parental, tribal ou étnica; e doravante grupos políticos militantes,

Madraça: termo genérico para designar uma escola, atualmente é usado para designar os seminários. 
muitas vezes armados. A 'islamização' não teve também as mesmas implicações para todas as mulheres: o estatuto das jovens profissionais do comércio, das bancárias de alto nível, das mulheres médicas, das universitárias, das pilotas e das engenheiras difere radicalmente daquele das mulheres que vivem, em sua maioria, no meio rural, cuja vida parece ter estagnado em outro século, cujo entorno imediato não foi afetado por desenvolvimentos externos e que estão sob o controle estrito dos machos da sua família e da sua comunidade. De acordo com pesquisas empíricas, o que as pessoas querem é se assegurar de que as leis não sejam contrárias à religião e não que se lhes imponha um dogma religioso (Shaheed 2002). Mas a ignorância generalizada, tanto das leis estatais quanto dos preceitos religiosos, 'fazem a cama' daqueles que recorrem à retórica da justiça islamista para mobilizar as multidões, amordaçando qualquer oposição.

As mulheres estão pouco presentes na burocracia civil e judiciária assim como no sistema político, são marginalizadas na economia, possuem baixo poder organizacional e até mesmo dificuldade de resistir quando seus direitos servem de objeto de troca para apaziguar as forças conservadoras. A luta pela igualdade de gênero no Paquistão, ainda que determinada, foi objeto de um pequeno grupo de mulheres relativamente privilegiadas. Na medida em que elas tinham tido mais sucesso em modificar as normas sexuadas, elas se tornaram o principal alvo dos projetos de 'islamização', por serem portadoras de uma visão de mundo a ser combatida. Até os anos de 1970, as mulheres puderam impulsionar reformas graças principalmente a ligações pessoais com homens de poder. Porém geralmente, mesmo se os dirigentes acolheram as suas demandas, as medidas propostas permaneceram letra-morta. Por exemplo, desde 1955, os reiterados apelos em favor do emprego de pessoal feminino no ensino primário, para lutar contra a baixa taxa de alfabetização das mulheres, permaneceram sem resposta. As recomendações das comissões criadas de tempos em tempos foram amplamente ignoradas. A frequência dos regimes militares contribuiu para eliminar as mulheres dos postos de planejamento e de tomada de decisões políticas durante longos períodos, exceto pelas mulheres-álibis. 
Antes de Zia, as mulheres das classes média e superior podiam ignorar a maior parte das normas preconizadas pela direita religiosa. Os tomadores de decisão e formadores de opinião eram, na época, provenientes de meios conexos, pouco influenciados pelos ulemás, mas ao longo dos anos de 1970, a prosperidade econômica fez emergir novas classes. Os comerciantes, que sustentavam ideias mais conservadoras, dentre as quais as dos partidos político-religiosos, ganharam mais peso.

A batalha sobre os direitos das mulheres, geralmente colocados em termos religiosos, de um lado, e sobre os direitos do homem, de outro, opôs mulheres e homens de origem social diferente. A direita religiosa busca seus dirigentes e quadros na classe média inferior que aspira ascender socialmente, enquanto a maior parte das militantes pelos direitos das mulheres é constituída por profissionais liberais. Essa fratura apareceu claramente sob Zia, com a intensa polarização sobre a questão do Islã e das mulheres.

\section{OS ANOS ZIA: $1977-1988$}

Quando tomou o poder, o general declarou: "O Paquistão foi criado em nome do Islã (...). Eu considero a adoção de [um] sistema islâmico como um pré-requisito essencial".

Para tanto, ele iniciou a mudança radical de toda uma série de leis e de instituições públicas e reorientou a sociedade em direção à ortodoxia religiosa por medidas estatais diretas e pela concessão de um espaço sem precedentes para diversos grupos político-religiosos. Despreparadas para um choque frontal com o exército, com a religião e com o Estado, as mulheres não puderam impedir a dissolução gradual de conquistas em parte consideradas como certas. A margem de resistência era estreita e arriscada: os direitos humanos foram suspensos, os tribunais militares se movimentavam e os/as militantes políticos/as eram aprisionados/ as e torturados/as sem reservas - inclusive as mulheres, pela primeira vez. As mulheres urbanas das classes média e superior, cujos direitos e privilégios eram os mais ameaçados, iniciaram a resistência, encabeçada por profissionais liberais.

No plano jurídico, a independência havia conquistado para as mulheres uma série de direitos de jure - em igualdade com os homens 
- sendo a principal exceção o direito da família. Mas o fosso entre os direitos formais e os direitos reais era vasto, sem contar que poucas dentre as interessadas tinham conhecimento dessas conquistas, doravante ameaçadas. A rapidez com a qual foram suprimidas atesta o quanto elas eram vulneráveis, uma vez que beneficiavam apenas uma pequena minoria.

As leis 'islamizadas' serviram para conferir um verniz religioso ao uso da força. Em fevereiro de 1979, o infame decreto Hudood introduziu castigos desumanos: amputação, flagelo público, apedrejamento até a morte. Além da criminalização das relações sexuais consensuais (zina), as leis cobriam todo um leque de crimes sexuais, dentre os quais o estupro, o sequestro, assim como o roubo, a bebedeira (novo objeto de condenação) e o perjúrio. O artigo mais amplamente aplicado sobre a zina provocou enormes injustiças, sobretudo para as mulheres. O estupro e outros crimes sexuais eram assimilados à zina e a polícia estava autorizada a decidir a natureza da infração. Assim é que pais/ mães, que davam queixa por sequestro ao tentar anular um casamento 'inapropriado', viram, ao contrário, suas filhas acusadas de zina e presas quando a polícia não fornecia provas de casamento ou de coação. A zina tornou-se uma infração contra o Estado e o princípio de presunção de inocência foi suprimido. Enquanto um tribunal superior não derrubasse a sentença, a acusada se via aprisionada, condenada e estigmatizada. Paródia de justiça: as vítimas de estupro - às vezes grávidas - incapazes de fornecer as provas exigidas para condenar o acusado, eram então consideradas como tendo 'consentido' com as relações sexuais e eram condenadas por zina. Pior, as meninas, desde a puberdade, eram consideradas como responsáveis: crianças de nove anos se viram perseguidas como se fossem adultas.

O poder judiciário foi reestruturado: uma nova Corte Federal da Xaria (FSC) foi encarregada de decidir se os dispositivos legais estavam conforme ao Islã, e um sistema judiciário paralelo foi criado para assegurar o cumprimento das novas leis 'islâmicas'. Essas mudanças ocasionaram duas viradas decisivas. Primeiramente, a imprecisão do quadro legal possibilitou aos juízes fazerem prevalecer as suas próprias leituras do Islã sobre a dos textos jurídicos e a da jurisprudência, 
principalmente quando a Resolução sobre os Objetivos se torna parte substancial da Constituição, em 1985. Assim, a jurisprudência da FSC sobre a zina dava testemunho de um "julgamento moral chocante [...] da parte do tribunal em relação à mulher vítima/acusada" (Ahmad, 1998, p.13). Outras leis legitimaram a ideia do estatuto inferior das muçulmanas e do conjunto dos/as não muçulmanos/as (considerados/ as, de certa maneira, meio-humanos/as): por exemplo, em sua versão original, uma nova lei propôs que a indenização que lhes seria acordada por ferimentos ou morte (qisas e diyat) equivaleria à metade daquela atribuída aos homens muçulmanos.

Em segundo lugar, diversas mudanças jurídicas, tais como as leis sobre a blasfêmia ${ }^{4}$, encorajaram as pessoas individualmente a se tomarem por substitutas do Estado para fazer respeitar os novos costumes religiosos. Ocorreram numerosos assassinatos de não muçulmanos/ as e de muçulmanos/as, sem que jamais os/as culpados/as fossem punidos/as. Fechando os olhos para a violência em nome da religião, o Estado favoreceu a expansão de um fanatismo que chega às vias de fato. Isso durou bastante tempo depois do regime de Zia. A parte mais prejudicial da herança de Zia reside menos nas leis do que na gravidade da mudança de representações e de normas instigadoras de práticas fundamentadas no fanatismo, na intolerância e mesmo na violência, em nome da religião.

No plano social, essas medidas estatais agressivas, às quais se somam ações de elementos não vinculados ao estado, tolerados e às vezes mesmo patrocinados pelo Estado, contribuíram para que as noções de 'bom/boa muçulmano/a' e 'bom/boa paquistanês/a' se tornassem sinônimas. A religiosidade - através da exibição de práticas ortodoxas - tornou-se a marca registrada do governo: recitações obrigatórias do Corão em todas as cerimônias públicas, nos aeroportos, pausa para oração e espaços reservados em escritórios e lugares públicos, etc. $O$ estudo do Islã (islamiyat) se tornou obrigatório em todas as escolas ${ }^{5}$,

4 As leis modificadas sobre a blasfêmia não atribuem mais qualquer importância à motivação e possibilitam que as acusações formuladas a esse título sejam admitidas como provas.

5 Tecnicamente os não-muçulmanos têm outras opções, mas poucas escolas estão equipadas para oferecer tais cursos. 
acompanhando testes de acesso ao ensino superior (qualquer que fosse a área) e à função pública. Reescrita pelos novos manuais escolares, a história se tornou uma narrativa 'islâmica', eliminando os discursos de Jinnah e as verdades incômodas (tais como a oposição da maioria dos ulemás à criação do Paquistão). Graças ao apoio oficial, o pregador comum, que vivia antes da caridade e de subsídios ocasionais, e cuja presença era tolerada, mais do que desejada, se viu mais bem munido e ligado a círculos influentes.

A questão do gênero estava no cerne dos discursos - especialmente a moral sexual. A 'paquistanesa' tornou-se uma 'muçulmana' vestida de modo específico, de preferência silenciosa e invisível, formada - se ela o fosse - em determinadas áreas, em institutos à parte. Diferentemente do costume nacional para os homens, às mulheres se impôs o xador como 'indumentária islâmica' - obrigatória para todas as alunas, professoras e empregadas do setor estatal, a princípio, e do setor privado em seguida. As exortações oficiais à 'moralidade pública' incitavam os homens a admoestar, eventualmente até a agredir fisicamente qualquer mulher na rua que se considerasse estar vestida de modo impróprio, e o assédio sexual nos lugares públicos disparou. Sob a pressão da sociedade, as cristãs e as parses renunciaram às saias e aos vestidos e as camponesas punjabis aos seus sarongues. Sem que fosse necessário legislar, a posição oficial sobre a vestimenta islâmica se tornou uma norma cultural apagando qualquer diversidade.

A segregação sexual ocupava um lugar central: proibição de espetáculos misturando rapazes e moças nos colégios, tentativa de proibir aos homens médicos a prática da ginecologia e a autópsia de cadáveres femininos e às mulheres atletas a competição diante de homens. Com a retórica do Estado alguns professores se recusaram a dar aulas para alunas 'malvestidas', outros praticavam a segregação em suas salas e alguns se recusavam completamente a instruir meninas. Uma campanha governamental contra a obscenidade e a vulgaridade (bode expiatório da direita religiosa) insinuava que as mulheres, de certa maneira, eram em si mesmas obscenas. As apresentadoras de jornais televisivos, as convidadas e as atrizes de comerciais ou de filmes eram obrigadas a cobrir sistematicamente a cabeça, sob o risco de perder o emprego. 
As mídias estatais elogiavam as virtudes e a abnegação da dona de casa, acusando as 'outras' mulheres visíveis em público (primeiramente aquelas que trabalhavam), de serem a causa da desintegração da família, da perda dos valores morais, da corrupção e de outros males. Uma geração inteira foi impregnada pela ideia de que o único lugar das mulheres era o lar, seu único papel a reprodução e a maternidade, e o seu único direito a submissão aos homens.

Paradoxalmente, as interessadas reagiram mais contra as reformas jurídicas que afetavam menos as suas vidas pessoais do que contra as mudanças sociais que as atingiam mais. Certamente, as leis da zina afetaram primeiramente as mulheres pobres e analfabetas (apesar de alguns processos atingirem famílias ricas, urbanas e rurais), mas o assédio sexual transcendia as barreiras de classe, ainda que sua amplitude e consequências variassem: todas as mulheres sofriam maior hostilidade nos lugares públicos, aquelas que trabalhavam encontravam ainda mais obstáculos, inclusive em casa. As militantes feministas impediram a adoção de alguns projetos de lei e obtiveram emendas que limitavam a força prejudicial de algumas outras. Mas elas não podiam conter o avanço de atitudes retrógradas ditas religiosas, e elas não se concentraram nisso. Não por esquecimento, mas devido à necessidade de responder quase cotidianamente aos projetos perniciosos do Estado.

\section{A ERA PÓS ZIA}

Foram necessários vinte e sete anos e um parlamento presidido por um chefe do Estado Maior do Exército para modificar as leis da zina. As mudanças no plano social exigirão muito mais tempo: numerosos costumes introduzidos sob Zia tornaram-se normas intangíveis. A religião adquiriu um sentido mercantil, com seus símbolos afixados em carros, edifícios oficiais e privados, em lugares públicos e nas salas de estar; com sua linguagem adotada por bancos e empresas comerciais.

Entretanto, depois de onze anos de um regime misógino envolvido numa retórica islamista e apesar da forte presença de elementos político-religiosos, o Paquistão elegeu uma mulher como Primeira-Ministra: Benazir Bhutto. De 1988, data da morte de Zia, até 1999, quando os militares retomaram as rédeas do poder, quatro governos eleitos, mas minoritários, 
viram brevemente o dia, sem abalar significativamente o lugar do Islã no seio do Estado. Benazir Bhutto (1988-1990, 1993-1996) não conseguiu e Nawaz Sharif (1991-1993, 1996-1999) não se empenhou nisso.

Bhutto não pôde revogar nenhuma das ditas leis islâmicas de Zia, protegidas pela oitava emenda da Constituição, pois isso teria exigido uma maioria de dois terços no Parlamento. Todavia, diretivas permitiram reduzir o número de processos e o abuso de recursos às leis da zina; o apoio do governo permitiu pela primeira vez uma absolvição depois da reforma da lei sobre a blasfêmia, apesar das ameaças contra os advogados de defesa, os acusados e os juízes da audiência ${ }^{6}$; e novas emissões da rádio estatal favorável, aos direitos das mulheres, trouxeram à luz os problemas que elas enfrentavam. Esse governo, dirigido por uma mulher, atenuou instantaneamente a atmosfera opressora que reinava até então. Mas essas breves tréguas não puderam reverter a dinâmica em curso, o lobby militar-religioso permaneceu impermeável a qualquer controle democrático.

Não se poderia esperar que Sharif, herdeiro político de Zia, pusesse fim à 'islamização'. Ao contrário, com uma maioria de dois terços quando de seu segundo mandato, ele se dedicou a consolidar o poder absoluto por diversos vieses: assédio aos meios de comunicação, prisão de jornalistas, tentativas de fechar milhares de Organizações Não-Governamentais (ONGs), silenciamento da dissidência no seio do partido graças à $15^{\circ}$ emenda constitucional, mais conhecida sob o nome de 'projeto de lei Xaria'. Peça fundamental do edifício, ele propunha conferir um poder absoluto ao Primeiro-Ministro para melhor aplicar a lei islâmica, mas não chegou a obter o apoio do Senado antes de Sharif ser derrubado pelo general Musharraf, em $1999^{7}$.

Em seu discurso inaugural, este último prometeu a igualdade de tratamento a todos/as os/as cidadãos/ãs, qualquer que fosse a sua província de origem ou sua religião. Várias reivindicações de longa data

6 Por ocasião do processo de Salamat, Rehmat e Mansur Masih em 1994, Mansur foi morto ao deixar o tribunal, e um dos dois juízes foi assassinado em seguida.

7 N.T. Após o golpe de Estado em 1999, Pervez Musharraf assume oficialmente em 2001 a presidência do Paquistão, à frente da qual permanece até 2008. 
das mulheres - e das minorias ${ }^{8}$ - foram satisfeitas, inclusive o aumento significativo da proporção de mulheres nos órgãos eleitos. A medida legislativa mais importante foi, de longe, a lei de 2006 sobre a proteção das mulheres, que atenuou, senão mesmo, eludiu a totalidade do conteúdo das leis infamantes sobre a zina (as relações sexuais permaneciam sob a força da lei, mas as persecuções tornaram-se impossíveis). Ponto crucial: a lei extinguiu a ideia de que o simples fato de uma lei ser qualificada como islâmica a tornava sagrada e imutável.

Musharraf chamou o clero para "frear os elementos que usam a religião em prol de seus próprios interesses", prolongando ao mesmo tempo os pequenos acordos com os grupos político-religiosos. O número sem precedentes de eleitos saídos de suas fileiras em 2002 resulta, com certeza, da raiva contra o ataque militar norte-americano ao Afeganistão, mas também da decisão de conferir às madraças equivalência universitária para responder à nova exigência de que os/as candidatos/as fossem diplomados/as. A proporção de militantes armados não diminuiu e a influência dos talibãs suscitou insurreições armadas em algumas regiões.

Apesar de certo liberalismo e menor pressão em relação a mulheres executivas ou das classes média e superior, nenhum dirigente da era pós-Zia se arrogou o direito de suprimir o apoio do Estado aos defensores da ortodoxia religiosa. Prova disso é que o número de grupos religiosos na sociedade civil continua a crescer, assim como a religiosidade nas classes dirigentes, inclusive entre as mulheres.

\section{GÊNERO, JUSTIÇA E SOCIEDADE CIVIL}

Antes de ingressar na arena eleitoral, o Jamaat-i-Islami ${ }^{9}$ integrava a sociedade civil. A definição que dá Antônio Gramsci (1971) da sociedade civil crítica, qual seja, a de grupos autônomos que contestam o apareIho de Estado, sem serem membros dele, vai surpreendentemente ao encontro do objetivo de Maududi:

Tentar despertar e guiar a vontade popular para estabelecer os fun-

8 Entre elas: uma comissão permanente de mulheres, a modificação da lei sobre os tribunais de Família, cotas de mulheres no Senado e nos governos locais (33\% dos representantes eleitos diretamente), bem como a extinção de eleitorado separado das minorias promulgado por Zia.

9 N.T.:Movimento social conservador e um dos mais antigos partidos religiosos do Paquistão, tenso sido fundado na Índia por Sayyid Abul Ala Maududi.. 
damentos de nosso Estado sobre a lei e a constituição que nós, muçulmanos, consideramos como divinas [e] forjar as ideias, as crenças e os pontos de vista morais do povo num molde islâmico, reformar o sistema [...] e fazer renascer [...] comportamentos islâmicos em geral (citado por Rashid, 1986, p. 83).

Maududi, autor preferido dos grupos armados paraestatais e dos partidos religiosos, perseguiu assiduamente esses objetivos. Uma vez que a transformação do sistema político, administrativo e judiciário era prioritário aos olhos do Jl, este esforçou-se para tomar o controle dos estabelecimentos educativos e para reforçar a sua influência no seio da burocracia civil e militar. A distância entre as promessas políticas de igualdade de oportunidades e de justiça para todos/as, de um lado, e a dolorosa realidade da injustiça, das privações e da discriminação, do outro, confere um grande peso social às iniciativas políticas de ordem religiosa, sobretudo na ausência de movimentos progressistas.

Ao insistir no lado punitivo da lei, os atores político-religiosos substituem a fé no Islã pela legislação muçulmana. Os políticos islamistas buscam sistematicamente deslegitimar e erradicar as abordagens da fé contrárias às suas próprias convicções, sobretudo as tradições místicas do sufismo. Pluralistas e descentralizadas, muito populares em numerosas regiões do Paquistão, elas perdem terreno face ao crescimento do Islã wahabita-salafi, institucional e centralizado. Ironicamente, esse processo é em parte facilitado pelo ethos da modernização que confere uma importância sem precedentes, e cada vez mais exclusiva, à palavra escrita como única base válida de conhecimento. Isto desacreditou a tradição doméstica, pacifista e generosa imputada às mulheres: a tradição ligada à instituição que é a mesquita, mais centrada no texto escrito, encoraja os homens, em sua maioria, a uma interpretação mais literal da fé. Mesmo quando a educação se limita a algumas noções e habilidades básicas, somente a aptidão para a leitura oferece um público cada vez maior para os escritos prolíficos dos conservadores religiosos (Ahmed 2003).

Há que se reconsiderar a ideia de que a sociedade civil é, de modo geral, progressista, pois no Paquistão ela se preocupa, sobretudo, em se assegurar uma esfera de influência e de privilégios em detrimento dos 
direitos dos/as outros/as. Numerosos grupos político-religiosos negam explicitamente às mulheres e aos/às não-muçulmanos/as os benefícios que advém da pertença à 'comunidade'. Mesmo sem atividades militantes, a maioria das madraças engendram estreiteza de espírito e xenofobia; e há vínculos estreitos entre as madraças armadas, os grupos militantes e os partidos políticos religiosos. A instrução religiosa (dars), ao mesmo tempo através de grupos tradicionais informais e de novas academias 'modernas' (muito populares desde a era Zia entre as mulheres urbanas de todas as origens sociais), bem como os pregadores dos novos canais de televisão a cabo, propagam uma concepção religiosa que formula as questões de direitos e de normas sociais em termos de males e de pecados.

Os grupos da sociedade civil que se apresentam como religiosos são os que, seguramente, mais gozam de impunidade. Tivemos um exemplo por ocasião do fiasco da Mesquita Vermelha, em 2007, quando as mulheres da escola de Al-Hafsa, vestidas com xadores negros e armadas com bastões, insistindo sobre a 'corrupção' sexual e a incapacidade do governo em fazer justiça, foram projetadas para o centro da cena $^{10}$. A retórica dos grupos de obediência religiosa que preconizam a segregação sexual, o controle da sexualidade e o respeito pelos códigos de vestimenta, assim como o fato de associar o Ocidente e certos elementos da modernização à decadência, sobretudo da moral sexual, evoca o texto de Maududi (1939) sobre a condição da mulher no islã'1. Ele se endereçava, antes de tudo, às novas classes médias emergentes e justificava aí uma estrita divisão sexual do trabalho e da organização social - sem necessariamente prever o nível de violência que ela atingiria. O imam da Mesquita Vermelha afirmou:

10 Localizada na capital, Islamabad, a Mesquita Vermelha havia se tornado o coração de resistência às ordens do governo para demolir onze mesquitas não autorizadas no final de 2006. Alunos/as das escolas e dos seminários masculino e feminino da mesquita, respectivamente Al-Fareedia e Al-Hafsa, jogaram aí um papel central. Exigindo a retirada dessas ordens, as manifestações degeneraram em conflito armado que teve fim apenas em 10 de julho de 2007, após uma operação militar de grande escala ao longo da qual, de acordo com os números oficiais, oitenta agentes de segurança e cinquenta ativistas morreram. Os jornalistas estimaram o número de mortes em centenas e os grupos politico-religioso em milhares.

1 Purdah and the Status of Women in Islam (1939): Purdah significa literalmente 'cortina' e designa uma prática que impede os homens de verem as mulheres. 
Nós não toleraremos dança e música no Paquistão [...]. Nós não esperaremos mais [...]. Se um pequeno grupo de homens piedosos puderam tomar posse de Kabul, porque nós não poderíamos impor a lei da xaria no [Paquistão] [...] , onde nós somos milhares (Salahuddin, 2007).

Os/as militantes que o apoiavam, por sua vez, declararam: "Se (a sexualidade imoral é) o que querem os liberais, eles deveriam partir [...]. O Paquistão é nosso e [...] nós o purificaremos".

Mulheres jornalistas que visitavam o complexo da Mesquita Vermelha foram severamente lembradas da sua própria sexualidade, como testemunha uma delas:

Com a cabeça nua enquanto filmo, eu sinto o fardo de ser uma muIher, minha moralidade foi detalhadamente examinada. Eu tenho muita consciência da minha sexualidade que, como me ensinaram minhas irmãs de Hafsa, constitui uma possível ameaça num mundo puro. E eu me disse: apenas homens podem me dar tal sensação de vulnerabilidade! (Salahuddin, 2007).

As jornalistas constataram também que, se individualmente, estudantes alegavam defender os direitos das mulheres, o porte generalizado do xador preto as transformava imediatamente, as estudantes comuns, numa massa anônima, veemente e intransigente. A sua campanha de 'limpeza' implicou o ataque a estabelecimentos comerciais, a destruição de CDs e de DVDs, a tomada e ocupação de um edifício governamental. Se militantes 'laicas' dos direitos das mulheres tivessem empreendido tais ações, elas teriam sido presas imediatamente. Ao invés disso, o presidente desculpou essas 'jovens perdidas'.

O tratamento diferenciado do Estado coloca indubitavelmente as defensoras laicas da igualdade de gênero em posição de inferioridade na luta contra o militantismo religioso. Ainda que as militantes dos direitos humanos ameacem muito pouco os partidos político-religiosos, infinitamente mais numerosos, melhor organizados e que possuem recursos sem medida à sua disposição, elas são tidas como as principais adversárias nas polêmicas. Se os ataques verbais e físicos têm por objetivo intimidá-las 
e reduzi-las ao silêncio, tratá-las como 'agentes do Ocidente' tem por objetivo retirar delas toda a sua credibilidade e todo o apoio do público, mesmo objetivo das acusações contra as ONGs que têm projetos financiados por capitais estrangeiros, enquanto esquece-se comodamente da existência de fundos semelhantes para os grupos religiosos.

No Paquistão, a instrumentalização do Islã por grupos que não possuem um programa religioso definido, reforçou os que o têm, provocando mudanças draconianas que resultaram em profundo enraizamento da religião na sociedade e no Estado. Uma vez que as normas sociais foram modificadas, o Estado não tem mais necessidade de intervir para que estas sejam aplicadas. Sob Zia, as agressões sistemáticas contra as mulheres que desobedeciam às prescrições estatais de um código de vestimentas 'islâmico' vinham de atores não estatais masculinos, mais do que de funcionários do Estado. Ninguém foi executado/a por blasfêmia, mas muitos/as foram assassinados/as. A pressão do Estado atenuou-se depois de Zia, mas as transformações sociais operadas impõem outros tantos desafios. A capacidade de uma mulher resistir ao peso do lobby religioso depende de múltiplos fatores: sua pertença de classe, seus recursos financeiros, sua comunidade, sua família e, é claro, suas próprias aspirações. A resistência coletiva pressupõe outras dinâmicas.

O princípio de centralização, principal instrumento para assegurar o poder político, é articulado no campo social tanto quanto no político e no territorial (Gramsci 1971). As forças político-religiosas visam, portanto, conscientemente, a centralização num e noutro campo. Socialmente falando, as mulheres portando véu nas práticas religiosas ortodoxas tornam-se marcadores simbólicos do território político conquistado, graças ao seu engajamento no campo social e cultural. As militantes dos direitos humanos e da igualdade entre os sexos, pouco numerosas e frequentemente acusadas de estar 'a soldo do Ocidente', não possuem programa social ou marcador identitário equivalentes. Essas militantes, que desenvolveram projetos políticos reconhecidos em gestão governamental, ainda precisam elaborar estratégias no campo social: um projeto de sociedade e de cultura contra o discurso hegemônico político-religioso, que possibilite mobilizar o apoio de um maior número de pessoas à igualdade entre os sexos, em palavras e na prática. 
Acusar as militantes dos direitos das mulheres de serem 'ocidentais' ou 'ocidentalizadas' visa, indiretamente, fazer delas 'estrangeiras' que devem ser expurgadas do corpo social - sendo que o medo é o de que elas consigam adeptas em outros lugares, inclusive nas famílias mais conservadoras. Ainda que essencial, a tendência a dar destaque ao Estado como garantidor dos direitos passa ao largo da adoção de práticas religiosas ortodoxas - coisa que os dirigentes no poder hesitam também em atacar frontalmente. O discurso sobre o direito das mulheres em particular, e sobre os direitos humanos de forma mais ampla, teria mais eco se, sem abandonar as referências aos direitos internacionais, ele se ancorasse nas tradições sociais populares mais liberais da sociedade. É tão importante liberar a história das distorções forjadas sob Zia quanto fazer emergir outras realidades e tradições enraizadas. Durante os anos Zia, as militantes se serviram eficazmente da história do Paquistão, de Jinnah e de outros dirigentes para fazer face ao ponto de vista de seus adversários e para defender suas próprias posições (assim como interpretações mais liberais da religião). Na ausência de tal iniciativa, aquelas e aqueles que lutam pela igualdade de gênero correm o risco de se encontrar cada vez mais marginalizados/as e deslegitimados/as no seio de suas próprias sociedades.

Em última instância, no entanto, a resistência ou a implementação de mudanças é uma questão de poder. Ora, as mulheres têm pouco poder, tanto no Estado como na sociedade, e a sua capacidade de resistência depende frequentemente das alianças que elas conseguem tecer. Testemunha disso é o fato de que, no apogeu do programa de 'islamização' de Zia, o regime ignorou totalmente os protestos contra as injustiças e o tratamento discriminatório em relação às mulheres e aos/às não-muçulmanos/as. Mas o regime modificou rapidamente a lei depois de uma greve relâmpago dos transportes em escala nacional que ameaçava paralisar a economia, devido à condenação à pena de morte de um motorista de caminhão responsável pela morte acidental de um pedestre. As mulheres, enquanto grupo, simplesmente não têm tanto peso. Elas não formam um coletivo homogêneo, inúmeras são as diferenças que as separam, segundo a classe social e os privilégios, a cultura, a educação, as experiências pessoais ou as escolhas de vida. 
Elas pensam de forma diferente. Se a maioria das mulheres não se sente capaz de participar da resistência, um bom número delas subscreve os pontos de vista de grupos religiosos que elas defendem ativamente, como o evidenciam as mulheres de Al-Hasfa, enquanto outras simpatizam com tais opiniões.

Enfim, é importante lembrar que as mulheres vivem nos mesmos espaços sociopolíticos que os homens - mesmo as regras de pertencimento sendo diferentes de acordo com o sexo - e que os problemas de gênero se inscrevam no quadro geral do Estado e da sociedade.

\section{REFERÊNCIAS}

ABBAS Hassan. Pakistan's Drift into Extremism: Allah, the Army, and America's War on Terror. New York: M. E. Sharpe, 2005.

AHMAD, Nausheen. The Superior Judiciary: Implementation of Law and Impact on Women. In: SHAHEED, Farida; WARRAICH, Sohail Akbar; BALCHIN Cassandra; GAZDAR, Aisha (Eds.). Shaping Women's Lives: Laws, Practices and Strategies in Pakistan. Lahore: Shirkat Gah, 1998.

AHMED, Leila (2003). A Border Passage. Dossier 25, Outubro, 2003. London: WLUML, 2003.

GRAMSCI, Antonio. Selections from the Prison Notebooks of Antonio Gramsci. Edited and translated by Quintin Hoare and Geoffrey Nowell Smith. London: Lawrence and Wishart, 1971.

HUSSAIN, Zahid. Frontline Pakistan: The Struggle with Militant Islam. Lahore: Vanguard Books, 2007.

JALAL, Ayesha. The State of Martial Rule: The Origins of Pakistan's Political Economy of Defence. Lahore: Vanguard Books, 1991.

MAUDUDI, Sayyid Abul A'la. Purdah and the Status of Women in Islam. Lahore: Islamic Publications, 1939/1991.

RASHID, Abbas. Pakistan: The Ideological Dimension. In: KHAN. Asghar (Ed.). Islam, Politics and the State: The Pakistan Experience. London: Zed Books, 1986.

SALAHUDDIN, Aliya. Rendezvous with the 'Others'. Newsline, Julho, 2007.

SHAHEED, Farida. Imagined Citizenship: Women State and Politics in Pakistan. Lahore: Shirkat Gah, 2002.

SHAHEED, Farida; WARRAICH, Sohail Akbar; BALCHIN Cassandra; GAZDAR, Aisha (Eds.). Shaping Women's Lives: Laws, Practices and Strategies in Pakistan. Lahore: Shirkat Gah, 1998. 